\title{
Kinetic parameters estimation for increasing the efficiency of nutrient absorption in fruit trees
}

\author{
Betania Vahl de Paula ${ }^{1}$, Danilo Eduardo Rozane ${ }^{2}$, George Welligton Bastos de Melo ${ }^{3}$, \\ William Natale ${ }^{4}$, Anderson Cesar Ramos Marques ${ }^{5}$, Gustavo Brunetto ${ }^{6}$
}

Abstract - The selection of rootstocks presenting traits of interest, such as resistance to pests and diseases, and compatibility with scion capable of producing fruits attractive to the market, has revolutionized fruit crops worldwide. However, the enormous potential of plants to be selected based on their nutrient uptake efficiency is yet to be properly explored; it can be done based on knowledge about kinetic parameters such as Influx, Maximum uptake velocity, Constant ion affinity with the carrier, and Minimum concentration. The adaptation of a methodology elaborated for annual crops to set kinetic parameters, as well as the Brazilian development of the Influx software, enabled selecting not only peach rootstocks with different nutrient uptake capacities, but also observing the influence the grafting of a particular cultivar crown has on rootstock's ability to uptake a given nutrient from the soil. Thus, fruit tree rootstocks and cultivars can always be selected based on traits desired by fruit growers and consumers, with emphasis on yield and quality of fruits. They can also be more efficient in taking up nutrients from low natural-fertility soils that require lower nutrient amounts, a fact that increases fertilizer use rationalization and reduces environmental contamination processes resulting from excessive nutrient applications.

Index terms: mineral nutrition of fruit trees, fertilization, cultivars, nutrient influx.

\section{Estimativa de parâmetros cinéticos para aumentar a eficiência da absorção de nutrientes em frutíferas}

Corresponding author: behdepaula@hotmail.com

Received: October 23, 2020 Accepted: March 08, 2021

Copyright: All the contents of this journal, except where otherwise noted, is licensed under a Creative Commons Attribution License.

\section{(cc) $\mathbf{E Y Y}$}

Resumo - A seleção de porta-enxertos com características de interesse, como resistência a pragas e doenças, e compatibilidade com copa capaz de produzir frutos atrativos ao mercado, revolucionou as frutíferas em todo o mundo. No entanto, o enorme potencial das plantas de serem selecionadas com base em sua eficiência de absorção de nutrientes ainda não foi devidamente explorado; isso pode ser feito com base no conhecimento dos parâmetros cinéticos, como influxo, velocidade máxima de absorção, constante de afinidade do íon com o transportador e concentração mínima. A adaptação de uma metodologia elaborada para safras anuais, para definição de parâmetros cinéticos, bem como o desenvolvimento brasileiro do software Influx possibilitaram não só selecionar porta-enxertos de pessegueiro com diferentes capacidades de absorção de nutrientes, mas também observar a influência da enxertia de uma determinada cultivar copa na capacidade do porta-enxerto de absorver determinado nutriente do solo. Assim, porta-enxertos e cultivares de árvores frutíferas sempre podem ser selecionados com base em características desejadas pelos fruticultores e consumidores, com ênfase na produtividade e na qualidade dos frutos. Eles também podem ser mais eficientes na absorção de nutrientes de solos de baixa fertilidade natural que requerem maiores quantidades de nutrientes, fato que pode aumentar a racionalização do uso de fertilizantes e reduzir os processos de contaminação ambiental resultantes de aplicações excessivas de nutrientes.

Termos para indexação: Nutrição mineral de frutíferas, adubação, cultivares, influxo de nutrientes. 


\section{Introduction}

One of the greatest achievements of plants breeding programs lies on enabling the development of new cultivars capable of adapting to, and growing under, different soil and climate conditions. However, although this laborious path has been taken for several years, it still needs to be further explored. Species selection for crops grown based on seed or vegetative propagation, was the subject of several studies conducted worldwide (ELHITI et al., 2016; GEMENET KHAN, 2017).

Genetic improvement programs aim to select cultivars resistant to diseases and pests or with specific grains or fruits characteristics. However, the nutrient absorption efficiency of plants has not been considered when selecting new cultivars. The nutrient absorption efficiency can be estimated based on kinetic parameters, such as nutrient input (I), maximum absorption rate $\left(\mathrm{V}_{\max }\right)$, ion affinity with the carrier $\left(\mathrm{K}_{\mathrm{m}}\right)$ and minimum concentration required to start nutrient absorption by plants $\left(\mathrm{C}_{\text {min }}\right)$ (MICHAELIS MENTEN, 1913; PAULA et al., 2018).
The evaluation of kinetic parameters was performed initially in annual cultures, using the Claasen and Barber method with minor adaptations (Table 1). Studies focused on investigating kinetic parameters in annual plants often used the methodology by Claassen and Barber (1974), according to which, plants are acclimated in Hoagland nutrient solution for a certain period-of-time and, then, they are placed in containers filled with distilled water for 24 hours in order to deplete internal nutrient reserves. After this period, plants are expected to use $100 \%$ of their nutrient uptake capacity. After nutrient reserves are depleted, plants are exposed to a nutrient-based solution again and, over time, aliquots of the nutrient solution where plants are left to grow in are periodically collected and prepared for the analysis of the nutrient of interest. The methodology adopted by Claassen and Barber (1974) for maize cultivation suggests that 24 hours is the time taken by plants to reach their ideal "hunger" period, which refers to the period plants often take to deplete their internal nutrient reserves without presenting deficiency symptoms. However, nutrient accumulation in reserve organs - such as roots and stem - of young fruit trees is often higher than in annual crops. Thus, these plants require longer nutrient depletion periods, a fact that makes it necessary adjusting this methodology.

Table 1. Studies on kinetic parameters in annual cultures.

\begin{tabular}{cccc}
\hline Cultivation & Species & Method & Reference \\
\hline Corn & Zea mays L. & $\begin{array}{c}\text { Adapted from } \\
\text { Claassen and } \\
\text { Barber (1974) }\end{array}$ & $\begin{array}{c}\text { (CLAASEN and BARBER, 1974). } \\
\text { (HORN et al., 2006). }\end{array}$ \\
\hline \multirow{2}{*}{ Soybean } & Glycine max cv Williams $w$ & $\begin{array}{c}\text { Adapted from } \\
\text { Claassen and } \\
\text { Barber (1974) }\end{array}$ & (CATALDO et al., 1983). \\
\hline
\end{tabular}

Brassiea napus L., Sinapis alba L.,

Rapeseed, mustard, Brassiea rapa L, Raphanus sativus radish, berseem $\quad$ L., Trifolium alexandrinum $L$., clover, crimson Trifolium incarnatum L., Phacelia clover, blue tansy, tanaeetifolia Benth., Loiium perenne ryegrass and rye.

L., Loiium multiforum Lam. and Secale cereale $L$

\author{
Adapted from \\ Claassen and (LAINE et al., 1993).
}

Barber (1974)
Adapted from

Claassen and (SILVEIRA and CARDOSO, 2004).

Barber (1974) 
Nowadays in breeding programs of fruit trees, aim at selecting rootstocks whose characteristics include compatibility with a broad spectrum of cultivars belonging to different species, good suitability for clonal propagation, reduced need hours of cold, water use efficiency, tolerance to soil or water salinity, resistance or tolerance to pests and diseases (MAYER PEREIRA, 2006; NAWAZ et al., 2016; PICOLOTTO et al., 2012; WARSCHEFSKY et al., 2016). These programs also make extensive use of genetic engineering and molecular biology techniques in order to better understand and broaden the genetic basis and map the genome of several species. This is done to enable the subsequent introduction of genes that are not often found in the original population, but that can develop characteristics of agronomic interest (CANAGUIER et al., 2017; CORNILLE et al., 2012; THUROW et al., 2017).

Recently, a Brazilian research group developed a methodology that allows an accurate evaluation of the kinetic parameters of young trees cultures. The aim of review is to highlight studies that show that the selection of rootstocks and fruit cultivars based on kinetic parameters of nutrient absorption is already possible. This advance can help farmers in Brazil and the world to select more productive fruit plants and can also be used to rationalize the use of fertilizers in orchards.

\section{The importance of the technique of evaluating kinetic parameters for fruit trees}

Most Brazilian soils are acidic and present low natural fertility. Thus, the soils require the application of acidity correctives and fertilizers to increase crop yield. However, most correctives and fertilizers used worldwide, mainly raw materials used to produce phosphate and potassium fertilizers, derive from finite capacity deposits. The final price of fertilizers fluctuates for a variety of reasons; they often account for more than $30 \%$ of the total production cost in fruit crops (AGRIANUAL, 2019). On the other hand, the use of fertilizers is essential to meet the food demand of the global population, which is expected to encompass 8.6 billion individuals by 2030 (ONU, 2018).

However, fertilizers are excessively applied "for safety" purposes without the adoption of proper technical criteria in many situations, a fact that can contaminate dietary items such as fruits, vegetables and grains (COUTO et al., 2018). Part of the nutrients applied above plants' demand and soil adsorption capacity can contaminate surface water adjacent to croplands due to surface (GIROTTO et al., 2010) and subsurface runoff, mainly in sandy soils with low organic matter content (BRUNETTO et al., 2015; LORENSINI et al., 2017; SCHMITT et al., 2017; SETE et al., 2015). Such contamination leads to imbalanced growth of microorganisms and to water eutrophication - a process that makes it unfit for human and animal consumption (MACHADO et al., 2016; SERIO et al., 2018; SHARMA BHATTACHARYA, 2017).

Thus, it is necessary developing strategies focused on rationalizing fertilizer use, as well as, on maintaining fruit yield and quality with low environmental impact. Accordingly, kinetic parameters associated with nutrient uptake $\left(\mathrm{V}_{\max }, \mathrm{K}_{\mathrm{m}}\right.$ and $\left.\mathrm{C}_{\min }\right)$ by rootstocks or cultivars (MARTINEZ et al., 2015), can help selecting plants adapted to soils with lower and higher natural fertility or to those that need higher (or lower) doses (or frequency) of nutrient application (PAULA et al., 2018).

The use of kinetic parameters associated with nutrient uptake also reduces investments in labor resources, which are increasingly scarce in orchards worldwide, or in equipment and fuel used in management-practice operations such as fertilization and fertilizer production (GARCÍA GARCÍA, 2013).

\section{Methodology suggested to help finding kinetic parameters associated with nutrient uptake by fruit trees}

Studies focused on estimating kinetic parameters in crop groups, such as fruit trees, remain scarce in the literature, mostly due to the hard time estimating such parameters, since fruit trees and forest species, even the young and on-growing ones, accumulate nutrients in their organs, mainly in roots - these nutrients are not depleted within 24 hours. Thus, a pioneering experimental methodology was developed, where the roots of 18-month-old peach plants were washed in distilled water and then each plant was placed in a pot (capacity: 7 L) filled with $25 \%$ Hoagland nutrient solution ionic strength (JONES JR., 2004) and acclimatized for 21 days. The whole Hoagland nutrient solution comprised $\left(\mathrm{mg} \mathrm{L}^{-1}\right): \mathrm{N}^{-\mathrm{NO}_{3}}{ }^{-}=196$; $\mathrm{N}^{-N_{4}}{ }_{4}^{+}=14 ; \mathrm{P}=31 ; \mathrm{K}=234 ; \mathrm{Ca}=160 ; \mathrm{Mg}=48.6$; $\mathrm{S}=70 ; \mathrm{Fe}-\mathrm{EDTA}=5 ; \mathrm{Cu}=0.02 ; \mathrm{Zn}=0.15 ; \mathrm{Mn}=0.5$; $\mathrm{B}=0.5$ and $\mathrm{Mo}=0.01$.

The solution in each pot was kept under constant aeration, which was performed by using polyethylene tubes connected to an oil-free mini air compressor. The solution was changed every three days during acclimation and the $\mathrm{pH}$ of all solutions was adjusted to $6.0 \pm 0.2$, on a daily basis, based on the addition of $1.0 \mathrm{~mol} \mathrm{~L}-1 \mathrm{HCl}$ (to acidify the solution) or $1.0 \mathrm{~mol} \mathrm{~L}^{-1}$ $\mathrm{NaOH}$ (to alkalize it). After the acclimation period was over, the nutrient solution was replaced by $0.01 \mathrm{~mol}$ $\mathrm{L}^{-1} \mathrm{CaSO}_{4}$ solution, and plants remained in it for up to 30 days to enable the depletion of internal nutrient reserves, except for $\mathrm{Ca}$ and $\mathrm{S}$, which maintained the 
potential of root cell membranes and prevented cell membrane denaturation (PAULA et al., 2018).

After the depletion period was over, plants were subjected to the Hoagland nutrient solution containing $50 \%$ of the original concentration again. They remained in this solution for one hour to enable the system to meet steady state uptake conditions in other words, to simulate what happens with plants grown in the soil, which continuously uptake nutrients, based on the kinetic model suggested by Claassen and Barber (1974). Next, the Hoagland nutrient solution containing $50 \%$ of the original concentration was replaced again and its $\mathrm{pH}$ was adjusted to enable aliquot collection. The total collection period and the interval between collections must be defined according to plant species, based on preliminary tests conducted for approximately 60 hours. No solution replacement and/or pH adjustment was carried out during this period.

After the aliquot collection time was over, plants were removed from the pots and separated into leaves, stems and roots. Plant height and stem diameter were measured with the aid of a caliper. Fresh matter (FM) was weighed with the aid of a digital scale. The nutrient solution volume remaining in each pot was measured with the aid of a graduated beaker. Plant organs were oven dried under forced air circulation at $65^{\circ} \mathrm{C}$ until reaching constant mass, which was used to determine the respective dry matter (DM) mass of each organ. Dried organs were ground, prepared and subjected to chemical analysis. The collected solution was also subjected to chemical analysis.

\section{Promising results of plant selection processes based on kinetic parameters}

Studies focused on selecting cultivars, fruit tree rootstocks - for example vine, peach, pear, among others - or even clones of forest species such as eucalyptus, have been carried out based on the methodology presented above, and on the use of the Influx software to enable rapidly estimating kinetic parameters (KULMANN et al., 2020a; KULMANN et al., 2020b; SETE et al., 2020; PAULA et al., 2018). The study by Paula et al. (2018), which used Aldrighi, Clone 15 and Tsukuba 1 rootstocks, is an example of such studies. Based on their results, Tsukuba 1 rootstock presented higher $\mathrm{V}_{\max }$ and affinity $\left(\mathrm{K}_{\mathrm{m}}\right)$ with nitrate ion $\left(\mathrm{NO}_{3}^{-}\right)$than Aldrighi and Clone 15 rootstocks (Figure 1). Afterwards, Paula (2019) studied the influence of the graft on the kinetic parameters of the rootstock absorption evidencing a significant effect of the rootstock/scion combination (Table 2).

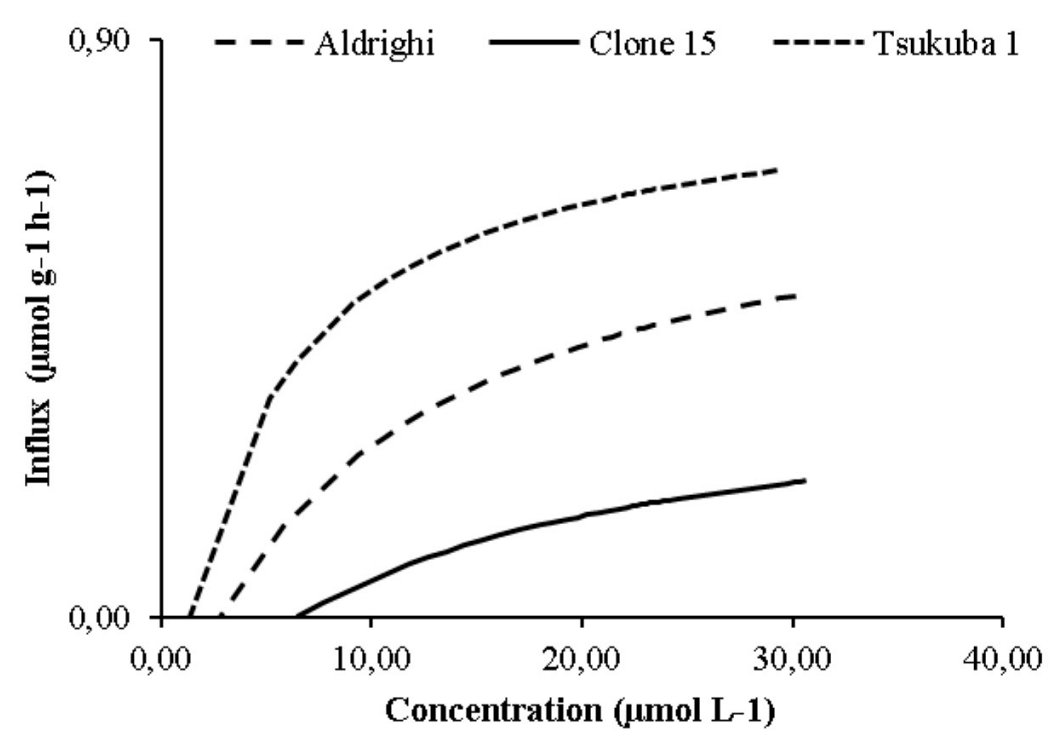

Figure 1. Maximum $\mathrm{NO}_{3}^{-}$influx determined in three clonal rootstocks of peach trees (approximately 18 months old). Source: Paula et al. (2018). 
Table 2. kinetic parameters of $\mathrm{NO}_{3}{ }^{-}$absorption $\left(\mathrm{C}_{\text {min }}, \mathrm{K}_{\mathrm{m}}\right.$ and $\left.\mathrm{V}_{\text {max }}\right)$ in pear, vine and eucalyptus used method by Paula et al. (2018).

\begin{tabular}{|c|c|c|c|c|c|}
\hline \multirow[b]{2}{*}{ Cultivation } & \multirow[b]{2}{*}{ Genetic material } & \multicolumn{3}{|c|}{ Kinetic parameters } & \multirow[b]{2}{*}{ Reference } \\
\hline & & $\underset{\left(\mu \mathrm{mol} \mathrm{g} \mathrm{g}^{-1} h^{-1}\right)}{V_{\max }}$ & $\underset{(\mu \mathrm{mol} \mathrm{L}}{\mathbf{K}_{\mathrm{m}}}$ & $\underset{(\mu \mathrm{mol} \mathrm{L}}{\mathrm{C}_{\min }}$ & \\
\hline \multirow[b]{2}{*}{ Peach } & Okinawa & 0.45 & 6.16 & 6.22 & \multirow[b]{2}{*}{ (PAULA, 2019). } \\
\hline & $\begin{array}{l}\text { Okinawa }+ \\
\text { Chimarrita }\end{array}$ & 0.44 & 4.33 & 3.59 & \\
\hline \multirow{2}{*}{ Pear } & Selection '54' & 0.34 & 3.59 & 1.24 & \multirow{2}{*}{ (SETE et al., 2020). } \\
\hline & Selection '971' & 0.58 & 1.19 & 0.43 & \\
\hline \multirow{2}{*}{ Vine } & Paulsen 1103 & 0.56 & 5.46 & 4.10 & \multirow{2}{*}{ (KULMANN, et al., 2020a). } \\
\hline & Magnolia & 0.57 & 6.62 & 7.80 & \\
\hline \multirow{2}{*}{ Eucalyptus } & E. saligna & 2.21 & 3.01 & 2.67 & \multirow{2}{*}{ (KULMANN, et al., 2020b). } \\
\hline & E. grandis & 2.11 & 1.53 & 3.10 & \\
\hline
\end{tabular}

Subsequent studies carried out on pear, vine, and eucalyptus seedlings at planting age, validated the method for other species (Table 2) and evidenced different kinetics parameters for different cultivar. The same is true of forest crops such as Eucaliptus. The results obtained so far show that it is possible to select cultivars that have greater affinity $\left(\mathrm{K}_{\mathrm{m}}\right)$ with certain nutrients and are able to absorb in low concentrations $\left(\mathrm{C}_{\text {min }}\right)$ to implant in areas with low nutrient content in the soil.

The results obtained in studies of kinetic parameters showed the potential of the proposed methodology to select the most nutrient uptakeefficient cultivars or rootstocks before they are made available in the market. Moreover, they enabled knowing whether selected plants can also adapt to different fertility conditions imposed on distinct soils from several fruit-growing regions countrywide. Furthermore, these results can help reducing the costs with adaptation tests applied to the most different cultivars of field species, since they can be used in the zoning of new cultivars. After all, the zoning of new cultivars is nothing more than implanting cultivar in several regions presenting the most varying microclimates and soil types. However, it generates costs with labor, machinery, fertilization, among others.

Moreover, a software was developed to help researchers calculate the $\mathrm{V}_{\max }, \mathrm{K}_{\mathrm{m}}$ and $\mathrm{C}_{\text {min }}$ parameters more quickly and accurately. The Influx software (Research Group for Prediction of Fertilization and Soil Contamination - GEPACES - www.gepaces. com.br) takes into account the nutrient concentrations measured in each collected rate (based on time), the volumes of the initial and final solution in the pots, as well as the fresh root mass.
The Influx software is an evolution of Cinética (Kinetics) software (RUIZ, 1992), which was the first nonlinear mathematical approximation software used to calculate kinetic parameters such as $\mathrm{V}_{\max }$ and $\mathrm{K}_{\mathrm{m}}$. The Cinética software is not easily used on current platforms, since data must be inserted one by one and results are provided in .txt format, without graphs. On the other hand, the Influx software allows importing data into Excel spreadsheets and adjusts the equation based on plant intake, as well as exports $\mathrm{V}_{\max }, \mathrm{K}_{\mathrm{m}}$ and $\mathrm{C}_{\min }$ results and the nutrient Influx graph to Excel. These characteristics make Influx a more accurate and user-friendly tool.

The net influx (NI) of each moment of kinetic intake rate is calculated based on equation 1 , which was suggested by Michaelis-Menten and modified by Nielsen and Barber (1978).

$$
\text { Equation } 1 \quad \boldsymbol{L}=\left[\frac{\boldsymbol{V}_{\max } \times\left(C-C_{\min }\right)}{K_{m}+\left(C-C_{\min }\right)}\right]
$$

where: $\mathrm{I}=$ nutrient influx rate, $\mathrm{C}=$ nutrient concentration in each collection period, $\mathrm{V}_{\max }=$ maximum nutrient uptake rate, $\mathrm{K}_{\mathrm{m}}=$ Michaelis-Menten constant, and $\mathrm{C}_{\min }=$ minimum nutrient concentration.

Results are recorded for each sample unit, variance analysis assumptions is tested, and $\mathrm{V}_{\max }, \mathrm{C}_{\min }$ and $\mathrm{K}_{\mathrm{m}}$ results can be subjected to mean comparison tests. 


\section{Conclusions}

Estimating kinetic parameters is a viable strategy used to select nutrient-uptake efficient cultivars, rootstocks or their clones, since it enables rationalizing fertilizer use, as well as assuring proper plant growth with high yield and financial profitability, without losing quality.

The methodology presented in the current study, in association with the Influx software - which was first developed in Brazil - can be adopted in plant breeding programs worldwide, for the most different plant species, including fruit trees, at low cost and quite fast.

\section{Acknowledgment}

The authors are grateful to the Coordination for the Improvement of Higher Education Personnel (CAPES - Coordenação de Aperfeiçoamento de Pessoal de Nível Superior) - Financial Code 001; to the National Council for Scientific and Technological Development (CNPq - Conselho Nacional de Desenvolvimento Científico e Tecnológico) and to Rio Grande do Sul Research Support Foundation (FAPERGS - Fundação de Amparo à Pesquisa do Rio Grande do Sul) for the partial funding of the study. They are also grateful to $\mathrm{CNPq}$, for granting the research productivity scholarship to the last three authors.

\section{References}

AGRIANUAL.Anuário da agricultura brasileira.23. ed. São Paulo: FNP, 2019.

BRUNETTO, G.; MELO, G.W.B. de; TOSELLI, M.; QUARTIERI, M.; TAGLIAVINI, M. The role of mineral nutrition on yields and fruit quality in grapevine, pear and apple. Revista Brasileira de Fruticultura, Jaboticabal, v.37, n.4, p.1089-1104, 2015.

CANAGUIER, A.; GRIMPLET, J.; DI GASPERO, G.; SCALABRIN, S.; DUCHÊNE, E.; CHOISNE, N.; MOHELLIBI, N.; GUICHARD, C.; ROMBAUTS, S.; LE CLAINCHE, I.; BÉRARD, A.; CHAUVEAU, A.; BOUNON, R.; RUSTENHOLZ, C.; MORGANTE, M.; LE PASLIER, M.-C.; BRUNEL, D.; ADAMBLONDON, A.-F. A new version of the grapevine reference genome assembly and of its annotation. Genomics Data, Amsterdam, v.4, p.56-62, 2017.
CATALDO, D.A.; GARLAND, T.R.; WILDUNG, R.E. Cadmium uptake kinetics in intact soybean plants. Plant Physiology, Lancaster, v.73, n.3, p.844848, 1983.

CLAASSEN, N.; BARBER, S.A. A method for characterizing the relation between nutrient concentration and flux into roots of intact plants. Plant Physiology, v.54, n.4, p.564-568, 1974.

CORNILLE, A.; GLADIEUX, P.; SMULDERS, M.J.M.; ROLDÁN-RUIZ, I.; LAURENS, F.; LE CAM, B.; NERSESYAN, A.; CLAVEL, J.; OLONOVA, M.; FEUGEY, L.; GABRIELYAN, I.; ZHANG, X.G.; TENAILLON, M.I.; GIRAUD, T. New insight into the history of domesticated apple: secondary contribution of the European wild apple to the genome of cultivated varieties. PLoS Genetics, San Francisco, v.8, n.5, 2012.

COUTO, R. da R.; MARTINI, L.C.P.; GATIBONI, L.C.; FILHO, P.B.; MARTINS, S.R.; LAZZARI, C.J.R.; JÚNIOR, V.M.; COMIN, J.J.; WITHERS, P.J.A.; SCHENATO, R.B.; BRUNETTO, G. Vulnerability to contamination by phosphorus in a zero-order basin with a high density of pigs and a history of slurry addition: extrapolation of an index. Environmental Earth Sciences, Wageningen, v.77, n.4, p.144, 2018.

ELHITI, M.; WANG, H.; AUSTIN, R.S.; CHEN, B.; BROWN, D.; WANG, A. Generation of chemically induced mutations using in vitro propagated shoot tip tissues for genetic improvement of fruit trees. Plant Cell, Tissue and Organ Culture, Dordrecht, v.124, n.2, p.447-452, 2016.

GARCÍA, J.G.; GARCÍA, J.B. Economic evaluation of early peach (Prunus Persica L. batsch) commercial orchard under different irrigation strategies. Open Journal of Accounting, Irvine, v.2, n.4, p.99-106, 2013.

GEMENET, D.C.; KHAN, A. Opportunities and challenges to implementing genomic selection in clonally propagated crops. In: VARSHNEY, R.K.; SORRELLS, M.E.; ROORKIWAL, M. Genomic selection for crop improvement. Cham: Springer International Publishing, 2017. p.185-198. 
GIROTTO, E.; CERETTA, C.A.; SANTOS, D.R. dos; BRUNETTO, G.; ANDRADE, J.G. de; ZALAMENA, J. Formas de perdas de cobre e fósforo em água de escoamento superficial e percolação em solo sob aplicações sucessivas de dejeto líquido de suínos. Ciência Rural, Santa Maria, v.40, n.9, p.1948-1954, 2010.

HORN, D.; ERNANI, P.R.; SANGOI, L.; SCHWEITZER, C.; CASSOL, P.C. Parâmetros cinéticos e morfológicos da absorção de nutrientes em cultivares de milho com variabilidade genética contrastante. Revista Brasileira de Ciência do Solo, Viçosa, MG, v.30, n.1, p.77 $\square$ 85, 2006.

JONES JR., J. Hydroponics: a practical guide for the soilless grower. Boca Raton: CRC Press, 2004.

KULMANN, M.S. de S.; SETE, P.B.; PAULA, B.V.; STEFANELLO, L.O.; SCHWALBERT, R.; SCHWALBERT, R.A.; ARRUDA, W.S.; SANS, G.A.; PARCIANELLO, C.F.; NICOLOSO, F.T.; MELO, G.W.B. de; SANTOS, H.P. dos; BRUNETTO, G. Kinetic parameters govern of the uptake of nitrogen forms in 'Paulsen' and 'Magnolia' grapevine rootstocks. Scientia Horticulturae, Wageningen, v.264, p.109-174, 2020a.

KULMANN, M.S. de S.; PAULA, B.V.; SETE, P.B.; ARRUDA, W.S.; SANS, G.A.; TAROUCO, C.P.; TABALDI, L.A.; NICOLOSO, F.T.; BRUNETTO, G. Morphological and kinetic parameters of the absorption of nitrogen forms for selection of Eucalyptus clones.

Journal of Forestry Research, Berlin, v.1, p.3, $2020 \mathrm{~b}$.

LAINE, P.; OURRY, A.; MACDUFF, J.; BOUCAUD, J.; SALETTE, J. Kinetic parameters of nitrate uptake by different catch crop species: effects of low temperatures or previous nitrate starvation. Physiologia Plantarum, Copenhagen, v.88, n.1, p.85-92, 1993.

LORENSINI, F.; CERETTA, C.A.; CONTI, L.De; FERREIRA, P.A.A.; DANTAS, M.K.L.; BRUNETTO, G. Nitrogen fertilization in the growth phase of "Chardonnay" and "Pinot Noir" vines and nitrogen forms in sandy soil of the Pampa Biome. Revista Ceres, Viçosa, MG, v.64, n.4, p.433-440, 2017.
MACHADO, C.S.; ALVES, R.I.S.; FREGONESI, B.M.; TONANI, K.A.A.; MARTINIS, B.S.; SIERRA, J.; NADAL, M.; DOMINGO, J.L.; SEGURAMUÑOZ, S. Chemical contamination of water and sediments in the Pardo River, São Paulo, Brazil. Procedia Engineering, Amsterdam, v.162, p.230 237, 2016.

MARTINEZ, H.E.P.; OLIVOS, A.; BROWN, P.H.; CLEMENTE, J.M.; BRUCKNER, C.H.; JIFON, J.L. Short-term water stress affecting NO 3 - absorption by almond plants. Scientia Horticulturae, Wageningen, v.197, p.50-56, 2015.

MAYER, N.A.; PEREIRA, F.M. Vigor de clones de umezeiro e pessegueiro "Okinawa" propagados por estacas herbáceas. Pesquisa Agropecuária Brasileira, Brasília, DF, v.41, n.5, p.883-887, 2006.

MICHAELIS, L.; MENTEN, M.M.L. The kinetics of invertin action. FEBS Letters, Amsterdam, v.587, n.17, p.2712-2720, 1913.

NAWAZ, M.A.; IMTIAZ, M.; KONG, Q.; CHENG, F.; AHMED, W.; HUANG, Y.; BIE, Z. Grafting: a technique to modify ion accumulation in horticultural crops. Frontiers in Plant Science, Lausanne, v.7, p.1457, 2016.

NIELSEN, N.E., BARBER, S.A., Differences among genotypes of corn in the kinetics of $\mathrm{P}$ uptake1. Agronomy Journal, Madison, v.70, p.695-698, 1978.

ONU. World population prospects 2018. New York: United Nations, 2018.

PAULA, B.V. Estratégias para aumentar a recuperação de nitrogênio em pessegueiro. 2019. Tese (Doutorado em Ciência do Solo) - Universidade Federal de Santa Maria, Santa Maria, 2019.

PAULA, B.V. de; MARQUES, A.C.R.; RODRIGUES, L.A.T.; SOUZA, R.O.S. de; KULMANN, M.S. de S.; KAMINSKI, J.; CERETTA, C.A.; MELO, G.W.B.de; MAYER, N.A.; ANTUNES, L.E.; RICACHENEVSKY, F.K.; NICOLOSO, F.T.; BRUNETTO, G. Morphological and kinetic parameters of the uptake of nitrogen forms in clonal peach rootstocks. Scientia Horticulturae, Wageningen, v.239, p.205-209, 2018. 
PICOLOTTO, L.; SCHMITZ, J.D.; PASA, M.D.S.; BIANCHI, V.J.; FACHINELLO, J.C. Desenvolvimento vegetativo e produtivo da cultivar "Maciel" em diferentes porta-enxertos. Ciência Rural, Santa Maria, v.42, n.6, p.969-974, 2012.

RUIZ, H.A. Cinética: software para estimar as constantes Vmax, Km da equação de MichaelisMenten. Revista Ceres, Viçosa, MG, v.32, n.179, p.79 $\square 84,1992$.

SCHMITT, D.E.; BRUNETTO, G.; SANTOS, E.dos; WAGNER, W.de L.; SETE, P.B.; SOUZA, M.; AMBROSINI, V.G.; SANTOS, M.A. dos; TIECHER, T.; COMIN, J.J.; COUTO, R.D.; GATIBONI, L.C.; GIACHINI, A. Phosphorus fractions in apple orchards in southern Brazil. Bragantia, Campinas, v.76, n.3, p.422-432, 2017.

SERIO, F.; MIGLIETTA, P.; LAMASTRA, L.; FICOCELLI, S.; INTINI, F.; DE LEO, F.; DE DONNO, A. Groundwater nitrate contamination and agricultural land use: a grey water footprint perspective in Southern Apulia Region (Italy). Science of The Total Environment, Amsterdam, v.645, p.14251431, 2018.

SETE, P.B.; MELO, G.W.B. de; OLIVEIRA, B.S.; FREITAS, R.F.; MAGRO, R.D.; AMBROSINI, V.G.; TRAPP, T.; COMIN, J.J.; GATIBONI, L.C.; BRUNETTO, G. Loss of soil nitrogen and peach yield with the addition of organic compost. Ciência Rural, Santa Maria, v.45, n.4, p.651-657, 2015.
SETE, P.B.; PAULA, B.V.; KULMANN, M.S. de S.; DE ROSSI, A.; ROZANE, D.E.; HINDERSMANN, J.; KRUG, A.V.; BRUNETTO, G. Kinetic parameters related to nitrogen uptake efficiency of pear trees (Pyrus communis). Scientia Horticulturae, Wageningen, v.272, p.109530, 2020.

SHARMA, S.; BHATTACHARYA, A. Drinking water contamination and treatment techniques. Applied Water Science, Berlin, v.7, n.3, p.1043-1067, 2017.

SILVEIRA, A.P.D. da; CARDOSO, E.J.B.N. Arbuscular mycorrhiza and kinetic parameters of phosphorus absorption by bean plants. Scientia Agricola, Piracicaba, v.61, n.2, p.203-209, 2004.

THUROW, L.B.; RASEIRA, M.do C.B.; BONOW, S.; ARGE, L.W.P.; CASTRO, C.M. Population genetic analysis of brazilian peach breeding germplasm. Revista Brasileira de Fruticultura, Jaboticabal, v.39, n.5, p.1-14, 2017.

WARSCHEFSKY, E.J.; KLEIN, L.L.; FRANK, M.H.; CHITWOOD, D.H.; LONDO, J.P.; VON WETTBERG, E.J.B.; MILLER, A.J. Rootstocks: Diversity, Domestication, and Impacts on Shoot Phenotypes. Trends in Plant Science, Amsterdam, v.21, n.5, p.418-437, 2016. 